\title{
Erratum: Neonatal Cerebellar Hemorrhage and Facial Nerve Palsy: An Unusual Association
}

Caterina Coviello, MD ${ }^{1}$ Giulia Remaschi, MD ${ }^{1}$ Sabrina Becciani, MD ${ }^{1}$ Simona Montano, MD luri Corsini, MD ${ }^{1}$ Federico Mussa, MD² Massimo Basile, MD ${ }^{3}$ Carlo Dani, MD¹,4

${ }^{1}$ Division of Neonatology, Careggi University Hospital of Florence, Florence, Italy

2 Department of Neurosurgery, Anna Meyer Children's Hospital, Florence, Italy

3 Interdisciplinary Specialist Department, Radiology Unit, Anna Meyer Children's Hospital, Florence, Italy

${ }^{4}$ Department of Neurosciences, Psychology, Drug Research and Child Health, Careggi University Hospital of Florence, Italy
Address for correspondence Carlo Dani, MD, Division of Neonatology, Careggi University Hospital, Largo Brambilla 3, 50141, Florence, Italy (e-mail: cdani@unifi.it).

\section{ERRATUM}

It has been brought to the publisher's attention that the page numbers appear incorrectly in the online version of the above article published in American Journal of Perinatology Reports, Volume 10, Issue 3, 2020 (10.1055/s-0040-1715162). The page numbers have now been corrected to e262-e265. (c) 2021. The Author(s).

This is an open access article published by Thieme under the terms of the Creative Commons Attribution-NonDerivative-NonCommercial-License, permitting copying and reproduction so long as the original work is given appropriate credit. Contents may not be used for commercial purposes, or adapted, remixed, transformed or built upon. (https://creativecommons.org/ licenses/by-nc-nd/4.0/)

Thieme Medical Publishers, Inc., 333 Seventh Avenue, 18th Floor, New York, NY 10001, USA 